Federal Reserve Bank of Minneapolis

Research Department Staff Report 212

May 1996

\title{
The Balance of Payments and Borrowing Constraints: An Alternative View of the Mexican Crisis*
}

\author{
Andrew Atkeson \\ University of Pennsylvania \\ and NBER \\ José-Víctor Ríos-Rull \\ Federal Reserve Bank of Minneapolis \\ and University of Pennsylvania
}

\begin{abstract}
In this paper we develop a model in which a country faces a balance of payments crisis if constraints on its international borrowing bind. We use the model to describe the dynamics of the trade balance, capital account, and balance of payments of a country that borrows to finance consumption following sweeping macroeconomic and structural reforms and then hits constraints on its international borrowing. We compare the predictions of this theoretical example with events in Mexico from 1987 through 1995.

*The views expressed herein are those of the authors and not necessarily those of the Federal Reserve Bank of Minneapolis or the Federal Reserve System.
\end{abstract}




\section{Introduction}

In this paper we examine the constraints placed on a government's exchange-rate and balance of payments policies in an economy in which international capital inflows are limited. In the context of a simple theoretical example, we describe the pressures on a country's central bank to sell its foreign exchange reserves when that country reaches its international borrowing constraint. We then use this example to study events surrounding the decision of the Banco de Mexico, during the last 10 months of 1994, to sell roughly $\$ 19$ billion of its foreign exchange reserves. ${ }^{1}$ We offer this model as an alternative to other accounts of the forces underlying the decision by the Banco de Mexico to sell its reserves, such as those offered in Dornbusch and Werner (1994), the International Monetary Fund (IMF) (1995b), Obstfeld and Rogoff (1995), and Rebelo and Végh (1995).

The scenario developed in our model is as follows. Consider a country whose residents and government, given world interest rates and the prevailing exchange rate, wish to spend in excess of national income. Imagine that such spending and the accompanying trade deficit continue until a constraint on international borrowing is reached. ${ }^{2}$ When this borrowing constraint is reached, the flow of foreign capital into the country stops and, at this point, the sale of the central bank's stock of foreign exchange reserves is the only remaining means by which the country can finance continued trade deficits. Thus the central bank loses reserves as long as the country runs a trade deficit. For the trade deficit to stop, either private expenditure must be reduced or current government expenditure must be cut.

From the central bank's perspective, binding constraints on residents' foreign borrowing appear as a drop in residents' demand for their government's debt. This drop in demand can be accommodated temporarily if the central bank sells its foreign exchange reserves and buys government debt; by doing so the bank bridges the gap between the outstanding stock of public debt and residents' declining demand for that debt at world interest rates and the fixed exchange rate. This expansion of domestic credit stops when the central bank becomes unwilling to sell its remaining reserves or exhausts its access to foreign borrowing to replenish those reserves.

Our model is broadly consistent with several aspects of recent events in Mexico. These events include the substantial increase in private spending, trade deficits, and capital inflows 
between 1988 and 1994, the sudden cessation of the flow of private portfolio investment into Mexico after the first quarter of 1994, the financing of Mexico's trade deficit for the remainder of 1994 by the sale of international reserves, the conduct of Mexico's monetary policy during 1994, the substantial increase in real interest rates in Mexico at the end of 1994, and the dramatic movement of Mexico's trade balance from deficit to surplus early in 1995. Our model does not account for the deep recession Mexico has experienced since it devalued the peso and is not consistent with the sharp drop in private consumption observed during that recession.

In Sections 2 and 3 we present our model and characterize equilibria with fixed exchange rates and international borrowing constraints. In Section 4 we present an example of a borrowing-constrained equilibrium. In Section 5 we present data from Mexico, compare them with our model, and discuss several other interpretations of the data. In Section 6 we conclude.

\section{A Model}

Ours is a model of a small open economy in discrete time. We refer to the private agents in this economy as the citizens. In addition, there is a government. We refer to the currency used in the rest of the world as the dollar. The price level in dollars is fixed and normalized to one. Let $q_{t+1}^{*}=\beta$ be the price paid in world capital markets in dollars at time $t$ for a one-dollar zero-coupon bond payable at time $t+1$. Let $P_{t}^{*}=\prod_{s=0}^{t-1} q_{s}^{*}=\beta^{t}$ be the price in dollars in world capital markets at time 0 for one dollar payable at $t \geq 1$. Let $P_{0}^{*}=1$. Both the citizens and the government of this economy take these prices as given. The government in this economy chooses sequences of expenditure, $g_{t}$; tax rates, $\tau_{t}$; bonds issued to domestic citizens, $b_{t+1}$; bonds issued to foreigners, $d_{t+1}$; foreign exchange reserves, $f_{t+1}$; and domestic money, $m_{t+1}$; we take initial stocks of government debt, $b_{0}, d_{0}$; reserves, $f_{0}$; and money, $m_{0}$, as given. We assume that all government bonds are one-period zero-coupon bonds denominated in dollars. Let $q_{t}$ be the price in dollars that citizens pay at time $t$ for a one-dollar zerocoupon bond issued by their government and payable at time $t+1$. Let $P_{t}=\prod_{s=0}^{t-1} q_{s}$ be the domestic price (in dollars) at time 0 for one dollar payable at $t \geq 1$. Let $P_{0}=1$. We refer

to the domestic currency as the peso and let $e_{t}$ be the nominal exchange rate. We assume 
purchasing power parity and we normalize the real exchange rate to one so that the domestic price level is given by $e_{t}^{-1}$.

The citizens in this economy are infinitely lived and have identical endowments and preferences. The representative citizen is endowed with output, $\left\{y_{t}\right\}_{t=0}^{\infty}$; an initial stock of foreign assets, $a_{0}$; an initial stock of government bonds, $b_{0}$; and an initial money stock, $m_{0}$. This agent chooses a sequence of consumption, $c_{t}$; foreign asset holdings, $a_{t+1}$; domestic bond holdings, $b_{t+1}$; and money holdings, $m_{t+1}$. This agent has preferences over consumption given by $\sum_{t} \beta^{t} u\left(c_{t}\right)$ and faces the following cash-in-advance, budget, and borrowing constraints:

$$
\begin{aligned}
c_{t} & \leq e_{t} m_{t} \\
q_{t}^{*} a_{t+1}+q_{t} b_{t+1}+e_{t} m_{t+1} & =y_{t}-\tau_{t}+a_{t}+b_{t}+e_{t} m_{t}-c_{t} \\
\lim _{t \rightarrow \infty} P_{t}^{*} a_{t+1}+P_{t} b_{t+1} & =0 \\
a_{t+1} & \geq-\bar{a}
\end{aligned}
$$

for some $\bar{a} \geq 0$.

In the last of these constraints we impose a tighter constraint on foreign borrowing by citizens than is imposed by the intertemporal budget constraint. We interpret this constraint as arising from limits on the extent to which foreign creditors can enforce the repayment of international debts. In particular, we assume that foreign creditors can seize only a limited portion of the endowment of a citizen who does not pay a debt and that the portion of the endowment that can be seized has value $\bar{a}$ to a foreign creditor.

To facilitate discussion of our results, we use the following terminology to distinguish between two components of government policy. Fiscal policy is the sequence of expenditure and tax rates $\left\{g_{t}, \tau_{t}\right\}_{t=0}^{\infty}$, and monetary policy is the sequence of money, government bonds of each type, and foreign exchange reserves $\left\{m_{t+1}, b_{t+1}, d_{t+1}, f_{t+1}\right\}$, chosen by the government of this economy. The government's budget constraint is given by

$$
\begin{aligned}
q_{t} b_{t+1}+q_{t}^{*}\left(d_{t+1}-f_{t+1}\right)+e_{t}\left(m_{t+1}-m_{t}\right) & =g_{t}-\tau_{t}+b_{t}+d_{t}-f_{t} \\
\lim _{t \rightarrow \infty} P_{t} b_{t+1}+P_{t}^{*}\left(d_{t+1}-f_{t+1}\right) & =0 .
\end{aligned}
$$


Since we distinguish between the government's gross international borrowing, $d_{t+1}$, and its gross international reserves, $f_{t+1}$, we require that $d_{t+1}, f_{t+1} \geq 0$.

We also impose a tighter constraint on the government's international borrowing, $d_{t+1}$, than would be implied by the government's budget constraint. Again, we interpret this constraint as arising from the risk of repudiation. Specifically, we assume that foreign lenders have limited sanctions that they could impose on this government if it were to default and that the transfers this government would be willing to make to avoid these sanctions have value $\bar{d}$ in world capital markets. We thus assume that foreign lenders to this government limit their lending so that

$$
d_{t+1} \leq \bar{d}
$$

We assume that foreign creditors cannot seize this government's foreign exchange reserves; thus this limit on foreign borrowing is not affected by the government's stock of reserves.

Given the initial conditions $b_{0}, d_{0}, a_{0}, m_{0}$, and $f_{0}$ and output $\left\{y_{t}\right\}$, an equilibrium is a fiscal policy, $\left\{g_{t}, \tau_{t}\right\}$; a monetary policy, $\left\{m_{t+1}, b_{t+1}, d_{t+1}, f_{t+1}\right\}$; prices, $\left\{q_{t}, q_{t}^{*}, e_{t}, P_{t}, P_{t}^{*}\right\}$; and an allocation for citizens, $\left\{c_{t}, a_{t+1}\right\}$, that satisfy the government's budget constraint and the government's foreign borrowing constraint and that maximize citizens' utility subject to their budget constraint, their foreign borrowing constraint, and their cash-in-advance constraint.

We distinguish between two particular types of equilibria. First, an equilibrium with fixed exchange rates is an equilibrium in which $e_{t}=e$. Second, an equilibrium with fixed exchange rates and unconstrained access to international borrowing is an equilibrium in which $e_{t}=e$ and $q_{t}=q_{t}^{*}$ for all $t$. In the first case, we allow that $q_{t}<q_{t}^{*}$ for some dates $t$. This event can occur in equilibrium if international borrowing constraints are binding.

At this point several remarks about our model are in order. We assume that the government can issue two classes of bonds, one to citizens and one to foreigners. This distinction becomes important in the model if the constraint on international borrowing binds and if bonds issued to citizens pay a higher real interest rate than is available in world capital markets. For most developing countries, during the 1970s and early 1980s the debt held by foreigners would typically have been loans from commercial banks in developed countries, while government treasury securities would have been held domestically. In this case classes 
of creditors to the government are easily distinguished. More recently, in the case of Mexico, foreign residents purchased substantial quantities of Mexican treasury securities; this made it more difficult to distinguish the nationality of the government's creditors. Yet data from the IMF (1995b, p. 62) indicate that by December 1994, most of the Cetes and Tesobonos in circulation were in foreign hands, suggesting that it may not have been that difficult to distinguish domestic from foreign holders of Mexican government debt.

In defining government policy, we assume that the government issues its debt in dollars. Since we are investigating the constraints that fiscal and monetary policies must satisfy to be consistent with permanently fixed exchange rates, our results would not be affected if we changed the denomination of this debt. It is clear that if we were to model explicitly the government's incentives to devalue or to default on its debt, we would need to consider the denomination of the government's debt more carefully.

We have not explicitly modeled the government's motivation to repay its debts. Several answers to the question of why governments repay their international debts have been explored in the literature on sovereign lending. ${ }^{3}$ One answer offered is that governments repay their current debts to avoid being excluded from access to foreign borrowing in the future. Other answers focus on the range of direct sanctions that foreign creditors and their governments might use to induce a debtor government to repay its debts: invasion; interference with trade, trade credit, and international transportation; or various types of diplomatic pressure. In both of these explanations, the maximum amount that foreign governments choose to repay is the outcome of a bargain in which debtors and creditors agree on the transfers the debtor makes to preserve future access to credit or to avoid direct sanctions. Foreign borrowing is then limited so as not to exceed the maximum value of these transfers. In this paper, we do not model the range of motivations government officials might have for repaying sovereign debts; nor do we model how these motivations might diverge from citizens' motivations for paying the taxes required to repay those debts. Instead, we simply assume that the maximum transfer that the government can be induced to make is constant and does not depend on the stock of foreign exchange reserves.

We also assume that the constraint on citizens' foreign borrowing does not depend on any actions that citizens or the government might take. For citizens, this assumption follows 
from our assumption that this is a deterministic endowment economy. Since there are no assets that citizens might use as collateral, private creditors' only recourse in the case of a citizen's bankruptcy is to convince the domestic courts to garnish that citizen's endowment stream. We assume that the value (evaluated at the world interest rate) of the endowment that the domestic courts will garnish is constant and is less than the value of the after-tax endowment stream itself. Thus private lending to citizens is limited.

\section{Characterization of Equilibria}

In this section we characterize the fiscal and monetary policies that are consistent with fixed exchange-rate equilibria and equilibria with fixed exchange rates and unconstrained access to international borrowing. We begin with a lemma that characterizes the path of the trade balance in equilibrium.

Lemma 1: In any equilibrium,

$$
\sum_{s=0}^{t} \frac{P_{s}^{*}}{P_{t}^{*}}\left(g_{s}+c_{s}-y_{s}\right)+\frac{1}{P_{t}^{*}}\left(d_{0}-f_{0}-a_{0}\right) \leq \bar{d}+\bar{a}
$$

for all $t$.

Proof: Subtraction of the citizen's budget constraint from the government's budget constraint gives the familiar equation that describes the evolution of the nation's net foreign indebtedness:

$$
q_{t}^{*}\left(d_{t+1}-f_{t+1}-a_{t+1}\right)=g_{t}+c_{t}-y_{t}+d_{t}-f_{t}-a_{t} .
$$

Iteration on this equation gives the equation

$$
d_{t+1}-f_{t+1}-a_{t+1}=\sum_{s=0}^{t} \frac{P_{s}^{*}}{P_{t}^{*}}\left(g_{s}+c_{s}-y_{s}\right)+\frac{1}{P_{t}^{*}}\left(d_{0}-f_{0}-a_{0}\right) .
$$

The constraints $d_{t+1} \leq \bar{d}, f_{t+1} \geq 0$, and $a_{t+1} \geq-\bar{a}$ give the inequality (1).

The next lemma characterizes citizens' consumption behavior in a fixed exchange-rate regime with unconstrained access to foreign borrowing.

Lemma 2: In any equilibrium with fixed exchange rates and unconstrained access to 
foreign borrowing, consumption $\left\{c_{t}\right\}_{t=1}^{\infty}$ is constant for $t \geq 1$ at $\bar{c}$. Consumption at date $0, c_{0}$ is given by $\min \left(\bar{c}, e m_{0}\right)$. The constant $\bar{c}$ is the largest constant such that

$$
\bar{c} \leq(1-\beta)\left(\sum_{t} P_{t}^{*}\left(y_{t}-\tau_{t}\right)+a_{0}+b_{0}+e m_{0}-\min \left(\bar{c}, e m_{0}\right)\right) .
$$

Seignorage for the domestic government is zero at all dates except date 0 . At date 0 , seignorage is given by $s_{0}=\bar{c}-e m_{0}$.

Proof: In this small open economy, under a fixed exchange rate, nominal interest rates are equal to world nominal interest rates. These interest rates are positive, so the citizen's cash-in-advance constraint is binding at all dates $t \geq 1$. From the first-order conditions of the citizen's utility maximization problem, we get the result that $\left\{c_{t}\right\}_{t=0}^{\infty}$ is constant when exchange rates are fixed $\left(q_{t}=q^{*}=\beta\right)$ and when the date 0 cash-in-advance constraint is not binding. In the case where the date 0 cash-in-advance constraint would be violated if $c_{0}=\bar{c}$, the value of $c_{0}$ is set so that the constraint binds. Seignorage at dates $t \geq 1$ is zero, since consumption, the exchange rate, and money holdings are constant. Seignorage at date 0 is equal to the difference between citizens' initial endowment of money and the money stock they choose to hold when they are first offered that choice.

We now review the results characterizing the constraints that fiscal and monetary policy must satisfy to be consistent with fixed exchange rates and unconstrained access to foreign borrowing.

Proposition: Given fiscal policy $\left\{g_{t}, \tau_{t}\right\}$, income $\left\{y_{t}\right\}$, and the initial conditions $a_{0}, b_{0}, d_{0}, f_{0}$, and $m_{0}$, let $\bar{c}$ and $c_{0}$ be defined as in lemma 2 . Then there exists an equilibrium with a monetary policy with fixed exchange rates and unconstrained access to international borrowing if and only if fiscal policy satisfies the solvency constraint

$$
\sum_{t} P_{t}^{*}\left(\tau_{t}-g_{t}\right)-\left(b_{0}+d_{0}-f_{0}\right)+s_{0}=0
$$


and if the cumulated trade balance satisfies

$$
\sum_{s=0}^{t} \frac{P_{s}^{*}}{P_{t}^{*}}\left(g_{s}+\bar{c}-y_{s}\right)+\frac{1}{P_{t}^{*}}\left(c_{0}-\bar{c}+d_{0}-f_{0}-a_{0}\right) \leq \bar{d}+\bar{a}
$$

for all $t$.

Proof: Begin with the second hypothesis. From lemma 2, in any equilibrium in which exchange rates are fixed and $q_{t}=q_{t}^{*}=\beta$ for all $t$, private consumption $c_{t}$ is constant at $\bar{c}$ for all $t \geq 1$, and the cash-in-advance constraints are binding. Hence the money supply is constant for $t \geq 1$ and seignorage is zero in all periods except date 0 . Seignorage at date 0 is given by $s_{0}=\bar{c}-e m_{0}$. Thus equation (3) follows from the government's budget constraint. Condition (4) follows from lemmas 1 and 2.

To prove the first hypothesis, consider $\left\{y_{t}\right\}$; the initial conditions $m_{0}, b_{0}, d_{0}, f_{0}$, and $a_{0}$; the fiscal policy $\left\{g_{t}, \tau_{t}\right\}_{t=0}^{\infty}$; and the initial seignorage $s_{0}$ which satisfy (3) and (4). We construct an equilibrium with fixed exchange rates as follows. Set $\bar{c}$ and $\left\{c_{t}\right\}$ as in lemma 1. Set $\left\{m_{t}\right\}_{t=1}^{\infty}$ constant at $\bar{c} / e$. Set $q_{t}=q_{t}^{*}=\beta$. Let $\left\{a_{t+1}\right\}$ be constant at $-\bar{a}$. Let $\left\{d_{t+1}\right\}$ be constant at $\bar{d}$. Use the citizen's budget constraint to define $\left\{b_{t+1}\right\}$. Use the government's budget constraint to construct $\left\{f_{t+1}\right\}$. Since (4) is satisfied, $f_{t+1} \geq 0$ for all $t$. By construction, $\lim _{t \rightarrow \infty} P_{t}\left(a_{t+1}+b_{t+1}\right)=0$. Since government policy satisfies $(3), \lim _{t \rightarrow \infty} P_{t}\left(d_{t+1}+b_{t+1}-\right.$ $\left.f_{t+1}\right)=0$.

The proposition demonstrates that fiscal and monetary discipline are not sufficient to ensure the viability of a fixed exchange rate together with unconstrained access to foreign borrowing. If trade deficits get too large, then international borrowing constraints will bind and monetary authorities will be forced to raise domestic real interest rates to defend their stock of international reserves, even if the fiscal, monetary, and fixed exchange-rate policies are both consistent with long-term fiscal balance and perfectly credible.

To contrast our result with existing results, in the following corollary we characterize the constraints fiscal and monetary policy must satisfy to be consistent with a fixed exchangerate regime in an economy in which there are either no constraints on the government's foreign borrowing or no constraints on citizens' foreign borrowing.

Corollary: Assume that there is no separate government foreign borrowing constraint 
$(\bar{d}=\infty)$. Given $e, m_{0}, b_{0}, d_{0}, f_{0}, a_{0}\left\{y_{t}\right\}$ and the fiscal policy $\left\{g_{t}, \tau_{t}\right\}_{t=0}^{\infty}$, define $s_{0}$ as in lemma 2. Then there exists an equilibrium with fixed exchange rates if fiscal and monetary policy satisfy (3). Moreover, if we assume that monetary authorities choose $b_{t+1}$ and $d_{t+1}$ to arbitrage away any difference between domestic and world interest rates, then, in any equilibrium with a policy of fixed exchange rates, the fiscal policy in that equilibrium satisfies the solvency constraint (3). Similarly, if $\bar{a}=\infty$, then there exists an equilibrium with fixed exchange rates if and only if fiscal policy satisfies the solvency constraint (3).

Proof: First observe that if $\bar{d}=\infty$ or $\bar{a}=\infty$, then (4) places no restrictions on equilibrium allocations. In the case of $\bar{d}=\infty$, since citizens are constrained in their foreign borrowing, we cannot rule out the possibility that $q_{t}<q_{t}^{*}=\beta$ for some $t$ unless we assume that the monetary authorities would arbitrage away the difference in bond prices. In the case of $\bar{a}=\infty$, citizens, being unconstrained in their borrowing, arbitrage away any differences in domestic and world interest rates, so $q_{t}=q_{t}^{*}=\beta$ for all $t$. The remainder of the proof follows directly from the proposition.

This corollary demonstrates that international borrowing constraints are relevant for determining the feasibility of a fixed exchange-rate policy only if both borrowing constraints exist. If either the government or citizens are unconstrained in their foreign borrowing, then the government can maintain any bounded path for reserves that it likes as long as its fiscal policy satisfies (3). This result is presented in Obstfeld (1986) and elsewhere. Moreover, without both borrowing constraints, the timing of trade balances is irrelevant for the viability of fixed exchange rates in this economy. All that is required is that fiscal policy be set such that no ongoing seignorage is required to finance fiscal deficits.

The result that ongoing seignorage is zero in a fixed exchange-rate regime is specific to this model. In general, the domestic government earns seignorage even in a fixed exchangerate regime. For instance, if we were to add growth in world output to this model and set world interest rates so that unconstrained domestic consumption grew at the growth rate of world output, then there would be growth in money demand and seignorage even in a fixed exchange-rate regime. This seignorage would be equal to the growth of domestic consumption. In this case, fiscal policy would need to satisfy only the constraint that taxes plus the seignorage obtained under fixed exchange rates pay for government expenditure. 
This is the qualitative theoretical result that would generalize to other models.

\section{An Example of a Borrowing-Constrained Equilibrium}

In this section we examine the balance of payments in an example economy in which the international borrowing constraints bind so that condition (4) in our proposition is violated. In this example we assume that the central bank maintains a fixed exchange rate and uses its stock of reserves to peg domestic interest rates to world interest rates until the stock of reserves is exhausted.

Consider an economy with the initial condition $b_{0}, d_{0}, f_{0}$, and $a_{0}$; with $y_{t}=y_{0}$, for $t=0,1,2, \ldots, T-1$; and with $y_{t}=y_{T}$ for $t=T, T+1, T+2, \ldots$, where $y_{T}>y_{0}$. Let $b_{0}=0$, $d_{0}=f_{0}=\bar{d}>0, a_{0}>\bar{a}$, and $e_{t}=e$ for all $t$. In setting these initial conditions, we impose the restriction that the public sector cannot increase its gross foreign borrowing, although it still has room to decrease its gross reserves. The private sector can increase its foreign indebtedness. Government spending is constant, $g_{t}=\bar{g}$, and $\tau_{t}=g_{t}-s_{t}$ for all $t$, so the government budget balances period-by-period.

We solve this example by guessing an equilibrium allocation. We construct the prices that support it and the paths for the fiscal and wealth variables that are consistent with it. We guess that the international borrowing constraints both bind in period $T-1$ and that, from period $T$ on, the citizens will choose a constant consumption, $c_{t}=\hat{c}_{T}$ for $t \geq T$, with

$$
\hat{c}_{T}=\left(y_{T}-\bar{g}\right)-(1-\beta)(\bar{d}+\bar{a}) .
$$

The last term in this expression is the interest on the foreign debt. We guess that first-period consumption is $c_{0}=\min \left(\hat{c}_{1}, e m_{0}\right)$ and that $c_{t}=\hat{c}_{1}$ for $t$ between $t=1$ and $t=T-1$, with

$$
\hat{c}_{1}=\left(y_{0}-g\right)+\frac{1-\beta}{1-\beta^{T}}\left(a_{0}+e m_{0}-\hat{c}_{0}\right)+\beta^{T} \frac{1-\beta}{1-\beta^{T}}(\bar{d}+\bar{a}) .
$$

Next we guess that prices $q_{t}$ are such that the household is induced to consume the indicated amounts. Since consumption is constant between periods 1 and $T-1$ and from period $T$ on, the price $q_{t}=\beta$ at those dates. At period $T-1$, the first-order conditions 
require that $q_{T-1}=\frac{\beta u^{\prime}\left(c_{T}\right)}{u^{\prime}\left(c_{T-1}\right)}=\frac{\beta u^{\prime}\left(\hat{c}_{T}\right)}{u^{\prime}\left(\hat{c}_{1}\right)}$. Since $\hat{c}_{T}>\hat{c}_{1}$, then $q_{T}<\beta$, so the real interest rate rises above the world interest rate at date $T-1$ when the international borrowing constraint binds.

Given the fixed exchange-rate policy, seignorage is zero at all dates except date 0 when $s_{0}=\hat{c}_{1}-\min \left(e m_{0}, \hat{c}_{1}\right)$ and date $T-1$ when $s_{T-1}=\hat{c}_{T}-\hat{c}_{1}$. The assumption of a fixed exchange rate also implies that the domestic price level is constant and that domestic nominal interest rates are equal to domestic real interest rates in every period. At date $T-1$, international interest rate parity does not hold.

To complete the description of equilibrium, we construct paths for the various assets, $b_{t+1}, a_{t+1}, d_{t+1}$, and $f_{t+1}$. After period $T$, reserves and public and private foreign indebtedness are at their limit values: $0, \bar{d}$, and $\bar{a}$. Before period $T$, however, the paths of these variables are not uniquely determined. Instead, the path of the country's total international indebtedness $\left(d_{t+1}-a_{t+1}-f_{t+1}\right)$ is determined by the path of the trade balance, the path of citizens' asset holdings $\left(a_{t+1}+b_{t+1}\right)$ is determined by their budget constraint, and the path of government debt $\left(d_{t+1}+b_{t+1}-f_{t+1}\right)$ is given by the government's budget constraint. Thus there is a continuum of possible paths of foreign reserves, $f_{t+1}$, that is consistent with equilibrium. These paths include one in which there is a temporary increase of foreign reserves financed on the government's part by issuing domestic government debt. Citizens increase their foreign indebtedness to finance their purchase of this extra domestic debt. For simplicity in constructing this example, we assume that the private sector first runs down its holdings of foreign assets until it reaches the limit $\bar{a}$; then it begins to sell its holdings of its government debt $b_{t+1}$. The central bank uses its foreign exchange reserves to purchase this debt. Of course, in period $T-1$, these reserves are exhausted.

It is straightforward to check that the constructed allocation and associated interest rates and paths for assets constitute an equilibrium: the allocation solves the maximization problem of the agent and satisfies the government's budget constraint.

In this example we assume that the central bank expends its international reserves and keeps domestic interest rates equal to world interest rates until those reserves are exhausted. As an alternative policy, the central bank may choose not to sell its foreign exchange reserves. For example, a country that runs a currency board commits its central bank not to purchase 
government debt, regardless of the level of domestic interest rates. The costs for the central bank of retaining its reserves can be understood as follows. When the international borrowing constraints bind, the central bank loses potential revenue if it holds foreign exchange reserves, because these reserves pay a lower interest rate than does domestic government debt. This loss of potential revenue could be large if domestic real rates rise substantially when the international borrowing constraints bind. Citizens also pay a price for this monetary policy. In particular, under this policy consumption is less smooth than if the central bank sold its reserves. Given the strict concavity of the utility function, it follows that a policy of maintaining high levels of foreign exchange reserves in the face of binding constraints on international lending has welfare costs. We do not intend to condemn currency boards or similarly tight reserve policies by this analysis. We intend only to point out the costs associated with such a policy. ${ }^{4}$

\section{Data From Mexico}

In this section we present data to establish eight facts:

1. Mexico experienced a substantial increase in private spending accompanied by large trade deficits and capital inflows from 1988 through 1994.

2. The flow of private portfolio investment into Mexico ended abruptly after the first quarter of 1994.

3. Mexico's trade deficit for the remainder of 1994 was financed largely by the sale of international reserves.

4. As the Banco de Mexico sold reserves during 1994, it increased domestic credit to maintain the monetary base.

5. Early in 1995, real interest rates in Mexico rose substantially.

6. Mexico's trade balance moved dramatically from deficits in 1988 through 1994 to a surplus in 1995.

7. By 1994 the cumulated stock of foreign investment in Mexico was large. 
8. Mexico experienced a severe recession in 1995.

Fact 1 is documented in tables 1 and 2. In table 1, we see that, from 1987 to 1994 , Mexico's current account relative to Gross Domestic Product (GDP) moves from a surplus of $2 \%$ of GDP to a deficit equal to $8 \%$ of GDP. Over the same time period, gross investment over GDP remains roughly constant, between $20 \%$ and $22 \%$, and public saving varies in the neighborhood of $5 \%$ to $7 \%$ of GDP. Private saving, however, drops from a peak of $19 \%$ of GDP in 1988 to a low of $9 \%$ of GDP in 1994. Thus, simply in terms of accounting, the increase in the current account deficit is largely explained by the drop in private saving from 1988 through 1994. Table 2 reinforces the data in table 1; it presents the current and capital accounts in dollar terms and documents the composition of the capital flows into Mexico. Observe that net capital inflows to the public sector are relatively small, except in 1993 . Net capital inflows to the private sector, however, match or exceed the growing current account deficit from 1989 through 1993. By 1993 the majority of that net capital inflow to the private sector is portfolio investment rather than direct investment. Over the same time period the central bank gradually acquires an additional $\$ 20$ billion in reserves.

Facts 2 and 3 are documented in tables 2 and 3 . In table 2 the net flow of portfolio investment into the private sector drops from $\$ 18$ billion in 1993 to $\$ 1.2$ billion in 1994 . In 1994 nearly two-thirds of the current account deficit of $\$ 29$ to $\$ 30$ billion is financed by selling the central bank's foreign exchange reserves. Table 3 presents Mexico's balance of payments for the year 1993 and quarterly for the first quarter of 1994 through the second quarter of 1995. This table differs from table 2 , in part because it reveals more information about the gross flow of capital both into and out of Mexico. Table 3 indicates that investment in the Mexican stock market and loans to commercial banks and the private sector in Mexico drop off dramatically beginning with the second quarter of 1994 . This financing totals roughly $\$ 30$ billion in 1993 and the first quarter of 1994 combined and only $\$ 1.3$ billion over the next three quarters (1994Q2-1994Q4). Errors and omissions and gross sales of foreign assets are not unusually large over the course of 1994, so there does not seem to be evidence of substantial unrecorded capital flight.

Fact 4 is documented in figure 1, which presents data on Mexico's monetary base and its components - international reserves and net domestic credit - from 1993 through 1995. 
The top line is reserves, the middle line is the monetary base, and the bottom line is net domestic credit. Figure 1 indicates that the Mexican central bank follows a policy of sterilizing the reserve loss over this time period; to keep the monetary base stable, the central bank acquires net domestic credit as it loses reserves.

Fact 5 is more difficult to document, since a real riskless security is not observed. The difference between Tesobono interest rates and U.S. short-term interest rates was in the range of $2 \%$ to $4 \%$ during most of 1994 . In the last week of 1994 it rose to $5 \%$; it then rose to nearly $20 \%$ by the end of January $1995 .{ }^{5}$ Since Tesobonos were indexed to the dollar, they did not have the same devaluation risk as Cetes, although they were subject to currency risks associated with dual exchange rates or other manipulations of the indexing scheme.

Fact 6 is documented in figure 2, which shows the dramatic adjustment of the trade balance into surplus early in 1995. This adjustment appears to run counter to any trends exhibited earlier by the trade deficit. In table 3 we see that the current account has a similarly dramatic adjustment from deficit in 1993 and 1994 to near balance in the first two quarters of 1995 .

To document fact 7 , we consult two sources on the cumulated stock of foreign investment in Mexico in 1994: the World Bank's World Debt Tables (1995) and Mexico's balance of payments statistics as reported in IMF (1995b). The World Debt Tables (1995) do not rate Mexico as a highly indebted country. Yet these tables are not a complete accounting of foreign capital flows into Mexico. In particular, over the time period from 1990 through 1993, Mexico's balance of payments statistics indicate that a total of $\$ 91$ billion in capital flowed into Mexico. ${ }^{6}$ Of this flow, $\$ 33$ billion is recorded in the World Debt Tables as the net flow on Mexico's total debt. These two sources can be reconciled in that the data from the World Debt Tables do not cover some of the major sources of foreign investment in Mexico. ${ }^{7}$ Some of the major investment flows that are left out are foreigners' direct investments in Mexico, foreign investments in Mexico's stock market, and the direct purchase of Mexican treasury securities by foreigners. Balance of payments accounts indicate that direct investment from 1990 through 1993 was $\$ 16.6$ billion, while foreign investment in Mexico’s stock market was $\$ 22$ billion. The IMF (1995b) indicates that foreigners' holdings of Mexican treasury securities totaled $\$ 22$ billion in December 1994. It is likely that most of this investment occurred 
after 1990. As noted in table 3, during the first quarter of 1994 Mexico received almost $\$ 10$ billion in capital inflows. These data are not inconsistent with the hypothesis that the ratio of the cumulated stock of foreign investment to exports in Mexico was roughly $270 \%$ to $310 \%$ in early 1994, or roughly the same level that it attained in 1982. In calculating the ratio of the cumulated stock of foreign investment in Mexico to GDP, it is also important to note that the dollar value of Mexico's GDP would certainly be considerably lower in 1995 than it was in 1993 or 1994 . Using a forecast ${ }^{8}$ of $\$ 266$ billion for the dollar value of Mexico's GDP in 1995 and a preliminary figure of $\$ 132$ billion for Mexico's total foreign debt $^{9}$ in 1994 , we estimate a ratio of total debt to GDP of $50 \%$, which is quite similar to the ratio for Mexico in 1982 , even if we do not include other forms of portfolio investment in the debt figure. If we use the larger figure of $\$ 188$ billion (including investments not covered in the World Debt Tables 1995) for the cumulated stock of foreign investment in Mexico, we estimate a debt-to-GDP ratio of $71 \%$, which is well in excess of the 1982 figure.

Finally, data on Mexico's GDP ${ }^{10}$ indicate that Mexico experienced a severe recession in 1995. Mexico's GDP for the first three quarters of 1995 was roughly $7 \%$ lower than its GDP for the first three quarters of 1994, while private consumption was down roughly $13 \%$ across these same time periods.

Our example in the previous section is consistent with the first seven of the eight facts documented above. In our example, increased private spending leads to trade deficits. Eventually, the private sector exhausts its ability to borrow from abroad. In applying our model to Mexico, we suggest that this occurred early in 1994. After this point, we suggest, the private sector financed its continued spending by selling its holdings of domestic assets. While we do not have balance sheets for the private sector that record these sales, the data indicate that the country as a whole financed its continued spending by selling its foreign exchange reserves. In our model, once the country is borrowing-constrained, the government must choose either to raise real interest rates to move the trade balance into surplus and stem the loss of reserves or instead to allow citizens to sell their remaining holdings of government bonds to the central bank to finance continued expenditure. We model Mexico's government as choosing the second option. This choice explains the dynamics of the monetary base and its components during 1994; the choice also served to hold down real interest rates in Mexico, 
despite the drop in domestic demand for Mexican government debt brought about by binding constraints on private foreign borrowing. Eventually, continued trade deficits exhausted both the government's ability to borrow abroad and the central bank's stock of foreign exchange reserves. At this point real interest rates rose and the trade balance moved into surplus.

Our model provides no explanation for fact 8, the recession in Mexico since 1995. Moreover, the path of private consumption observed in Mexico appears to be inconsistent with our model. Our model predicts there should be a decrease in the marginal utility of current consumption once borrowing constraints begin to bind. Thus, given standard assumptions on preferences, agents should not choose a path for consumption that is expected to drop when they become borrowing-constrained. This implication of our model should be compared to data on private consumption of nondurables and services. While we do not have data on

consumption of nondurables and services in Mexico as distinct from consumption of durables, we imagine that such consumption may well have dropped substantially in 1995.

In our model we do not distinguish between different types of international capital flows. In practice, the costs to a country of repudiating or nationalizing either foreign investment in its stock market or foreign direct investment must be different from the costs of repudiating bank loans or bonds written under domestic or foreign law. Events in Mexico suggest that it was the flow of portfolio investment in particular that stopped. Positive flows of direct investment into Mexico continued through 1995. It is interesting to note that positive flows of direct foreign investment into Mexico also continued throughout the 1980s. However, we speculate that it would have been costly for Mexico to induce a doubling or tripling of the inflow of direct foreign investment in 1994, as would have been required to replace the portfolio investment that stopped after the first quarter of that year.

\section{Conclusion}

We have presented a simple theoretical model of the balance of payments in an economy in which international capital flows are constrained by borrowing limits. As barriers to international capital flows have fallen during the last several decades, many analysts of the balance of payments have put aside models that include limits on international capital flows in favor of those that assume free international capital mobility. For example, models that rely on in- 
ternational borrowing constraints would not seem to be particularly useful for understanding the recent speculative attacks on Europe's Exchange Rate Mechanism. However, events in Mexico suggest that a model with borrowing constraints may still be useful for understanding balance of payments problems in some cases.

Many models of balance of payments problems - in particular, models of speculative attacks - assume that there is some state of nature in which the government abandons its exchange-rate targets and the restrictions implied by such targets on domestic fiscal and monetary policy. ${ }^{11}$ Our model clearly demonstrates that a country can experience balance of payments problems even if the government is committed to maintaining fiscal and monetary policies that are consistent with its exchange-rate targets in every state of nature. Moreover, our model suggests that countries undertaking important policy reforms should anticipate balance of payments problems if international borrowing constraints begin to bind. Given that the dynamics of Mexico's capital account and trade balance are consistent with the hypothesis that Mexico had hit its international borrowing constraint early in 1994, we suspect that the pressures on the Banco de Mexico to sell its foreign exchange reserves may have gone beyond investors' concerns over Mexico's commitment to its exchange-rate policies. 


\section{Footnotes}

${ }^{1}$ This amount is roughly 4-5\% of Mexican Gross Domestic Product in 1994 at mid-1994 exchange rates.

${ }^{2}$ We interpret the constraints on international borrowing imposed in this paper as arising from the risk that the borrower will not honor his contractual obligation to repay his debts.

${ }^{3}$ Eaton and Fernandez (1995) provide a recent review of this literature. Kaletsky (1985) and Alexander (1987) review the range of sanctions that international creditors have available for enforcing the repayment of international debts.

${ }^{4}$ It is clear that in these examples we do not consider the possible beneficial role a currency board or a policy of maintaining high reserves might have in establishing the credibility of monetary and exchange-rate policy.

${ }^{5}$ These data on interest rates are from Sachs, Tornell, and Velasco (1995).

${ }^{6}$ The following data on capital flows into Mexico are from the IMF International Capital Markets Report (1995b, p. 53) and from the World Bank's World Debt Tables 1994-1995. Data on foreigners' holdings of Mexican treasury securities are from the IMF International Capital Markets Report (1995b, chart I.10, p. 62).

${ }^{7}$ The World Debt Tables (1995) include only debt contracts not written under Mexican law. Thus debt contracts such as Cetes and Tesobonos are defined as domestic debt, even if held by foreigners.

${ }^{8}$ This forecast is from the Economist, July 15-21, 1995, p. 90.

${ }^{9}$ This figure for Mexico's total debt at the end of 1994 is from the Economist Intelligence Unit's Country Report for Mexico, 3rd quarter 1995, p. 3. The figures in this report for total 
debt for the years 1990-1993 are consistent with those in the World Debt Tables (1995).

${ }^{10}$ Our data on Mexico's GDP and private expenditure are from the Instistuto National de Estadistica, Geografia e Informatica's "Sistema de Cuentas Nacionales de Mexico."

${ }^{11}$ See Agénor and Flood (1994) for a survey. 


\section{References}

Agénor, P., and R. P. Flood, 1994, Speculative Attacks and Balance of Payments Crises, in F. van der Ploeg, ed., The Handbook of International Macroeconomics (Cambridge, Mass.: Basil Blackwell), pp. 224-250.

Alexander, L. S., 1987, Three Essays on Sovereign Default and International Lending, Ph.D. dissertation, Yale University.

Dornbusch, R., and A. Werner, 1994, Mexico: Stabilization, Reform and No Growth, Brookings Papers on Economic Activity 1, 253-315.

Eaton, J., and R. Fernandez, 1995, Sovereign Debt, in G. M. Grossman and K. S. Rogoff, eds., Handbook of International Economics, vol. 3 (Amsterdam: North-Holland).

International Monetary Fund, 1995a, World Economic Outlook, May.

International Monetary Fund, 1995b, International Capital Markets: Developments, Prospects, and Policy Issues, August.

Kaletsky, A., 1985, The Costs of Default (New York: Priority Press; A Twentieth Century Fund paper).

Obstfeld, M., 1986, Speculative Attack and the External Constraint in a Maximizing Model of the Balance of Payments, Canadian Journal of Economics 19, 1-22.

Obstfeld, M., and K. Rogoff, 1995, The Mirage of Fixed Exchange Rates, Journal of Economic Perspectives 9, 73-96.

Rebelo, S., and C. Végh, 1995, Real Effects of Exchange-Rate-Based Stabilization: An Analysis of Competing Theories, in B. Bernanke and J. Rotemberg, eds., NBER Macroeconomics Annual 1995 (Cambridge, Mass.: National Bureau of Economic Research), pp. 125-173.

Sachs, J., A. Tornell, and A. Velasco, 1995, The Mexican Peso Crisis: Sudden Death or Death Foretold? mimeo, Harvard University. 
World Bank, 1995, World Debt Tables 1994-1995: External Finance for Developing Countries, Washington, D.C. 
Table 1: Saving, Investment, and the Current Account in Percentages of GDP

\begin{tabular}{c|rrrrrrrr} 
& 1987 & 1988 & 1989 & 1990 & 1991 & 1992 & 1993 & 1994 \\
\hline National Saving & 21.6 & 18.2 & 18.5 & 18.7 & 17.6 & 16.0 & 14.1 & 13.7 \\
Private Saving & 14.3 & 18.8 & 16.1 & 12.1 & 10.0 & 8.7 & 8.9 & 9.1 \\
Public Saving & 7.3 & -0.7 & 2.4 & 6.6 & 7.6 & 7.3 & 5.2 & 4.6 \\
Gross Dom. Invest. & 19.3 & 20.4 & 21.4 & 21.9 & 22.4 & 22.8 & 20.6 & 21.6 \\
Current Account & 2.2 & -2.3 & -2.9 & -3.2 & -4.8 & -6.8 & -6.4 & -8.0
\end{tabular}

Source: IMF (1995a, p. 92).

Table 2: Financing of the Current Account in Billions of U.S. Dollars

\begin{tabular}{c|rrrrrrrr} 
& 1987 & 1988 & 1989 & 1990 & 1991 & 1992 & 1993 & 1994 \\
\hline Current Account & 2.9 & -3.8 & -6.1 & -7.5 & -14.9 & -24.8 & -23.4 & -29.5 \\
Capital Account & 3.8 & -2.9 & 5.1 & 10.9 & 22.5 & 26.7 & 30.5 & 11.6 \\
$\quad$ of Which & & & & & & & & \\
Public Sector Net & 3.6 & 1.2 & -0.7 & -0.2 & 3.0 & 1.5 & 7.5 & 2.5 \\
$\begin{array}{c}\text { Private Sector Net } \\
\text { of Which }\end{array}$ & 0.2 & -4.1 & 5.8 & 11.1 & 19.5 & 25.2 & 23.0 & 9.1 \\
$\begin{array}{c}\text { Direct Investment } \\
\text { Level (End-Yr. Gross) } \\
\text { For. Ex. Reserves }\end{array}$ & 1.8 & 1.7 & 2.7 & 2.6 & 4.8 & 4.4 & 4.9 & 7.9 \\
& 8.0 & 6.0 & 6.5 & 10.1 & 17.9 & 19.4 & 25.4 & 6.3
\end{tabular}

Source: IMF (1995a, p. 92). 
Table 3: Mexico's Balance of Payments 1993-1995Q1 in Billions of U.S. Dollars

\begin{tabular}{c|rrrrrrr} 
& 1993 & $94 \mathrm{Q} 1$ & $94 \mathrm{Q} 2$ & $94 \mathrm{Q} 3$ & $94 \mathrm{Q} 4$ & $95 \mathrm{Q} 1$ & $95 \mathrm{Q} 2$ \\
\hline Current Account & -23.4 & -6.7 & -7.1 & -7.7 & -7.3 & -1.1 & 0.5 \\
Capital Account & 32.6 & 9.9 & 0.1 & 4.9 & -3.3 & 2.5 & 1.2 \\
$\quad$ of Which & & & & & & & \\
Loans to Comm. Banks & & & & & & & \\
and Private Sector & 12.6 & 4.8 & -0.3 & -0.8 & 0.7 & -2.6 & -1.5 \\
Loans to Public Sector & 1.5 & 1.3 & 0.3 & 0.5 & 0.3 & 9.2 & 4.4 \\
Direct Investment & 4.4 & 1.8 & 1.6 & 2.3 & 2.2 & 1.0 & 1.6 \\
$\quad$ Stock Market & 10.7 & 3.5 & 0.2 & 0.7 & -0.4 & 0.1 & 0.1 \\
Money Market* & 7.0 & 1.5 & 0.0 & 1.2 & -4.7 & -4.7 & -3.4 \\
Sales of For. Assets** & -3.6 & -3.1 & -1.8 & 0.9 & -1.5 & -0.4 & 0.0 \\
Errors and Omissions & -3.1 & -2.3 & -2.4 & 2.6 & 0.5 & -0.7 & 1.4 \\
Change in Intl. Rsrvs. & 6.1 & 0.8 & -9.4 & -0.1 & -10.1 & 0.7 & 3.1
\end{tabular}

*The money market is for Mexican treasury securities.

**Minus signs here indicate Mexican accumulation of foreign assets.

Source: Banco de Mexico, Indicadores Economico, September 1995, Cuadro IV-1b. 


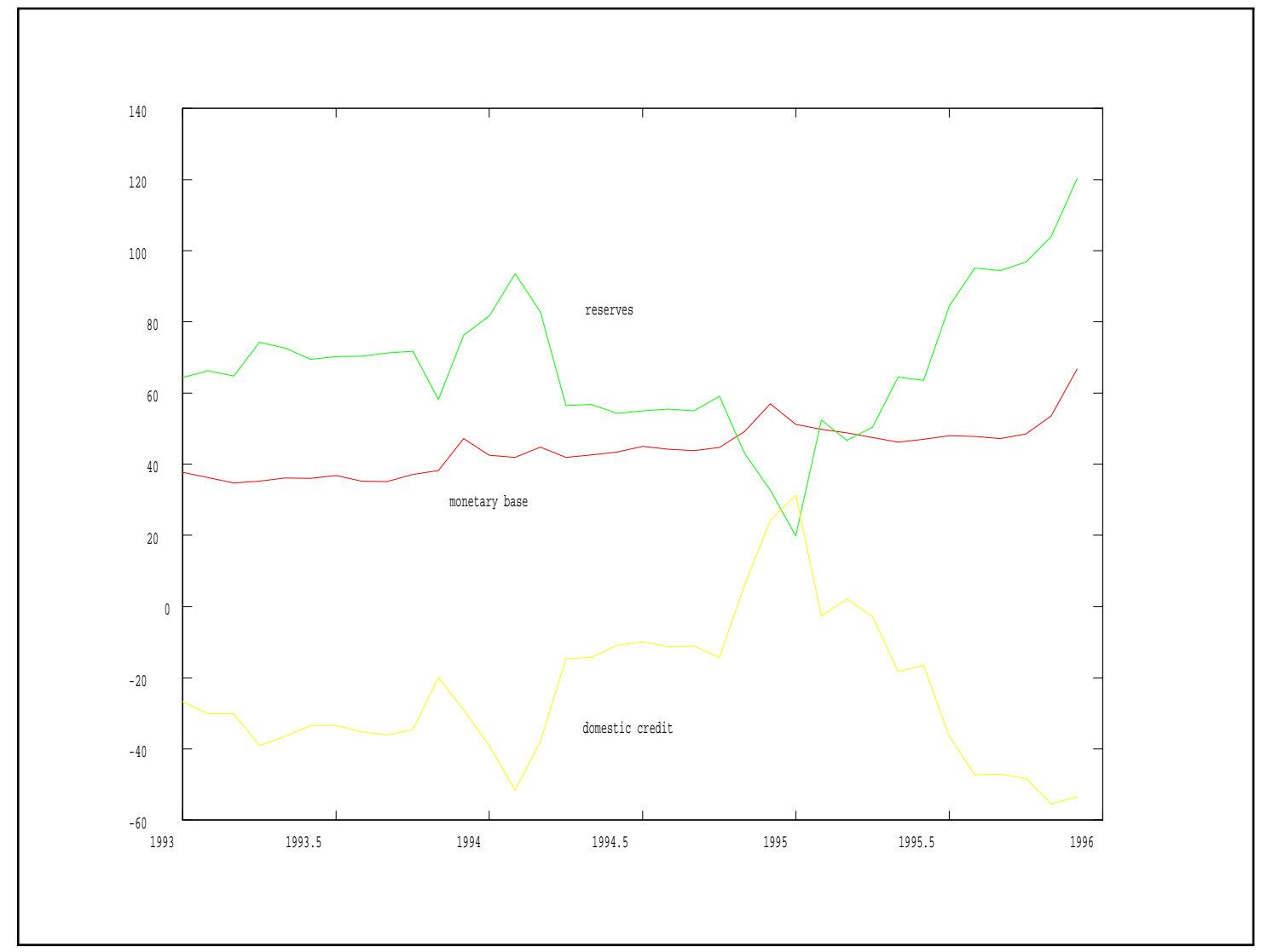

Figure 1: Mexico's Monetary Base and Components 1993-1995 in Billions of New Pesos. Source: Banco de Mexico, Indicadores Economico, various issues. 


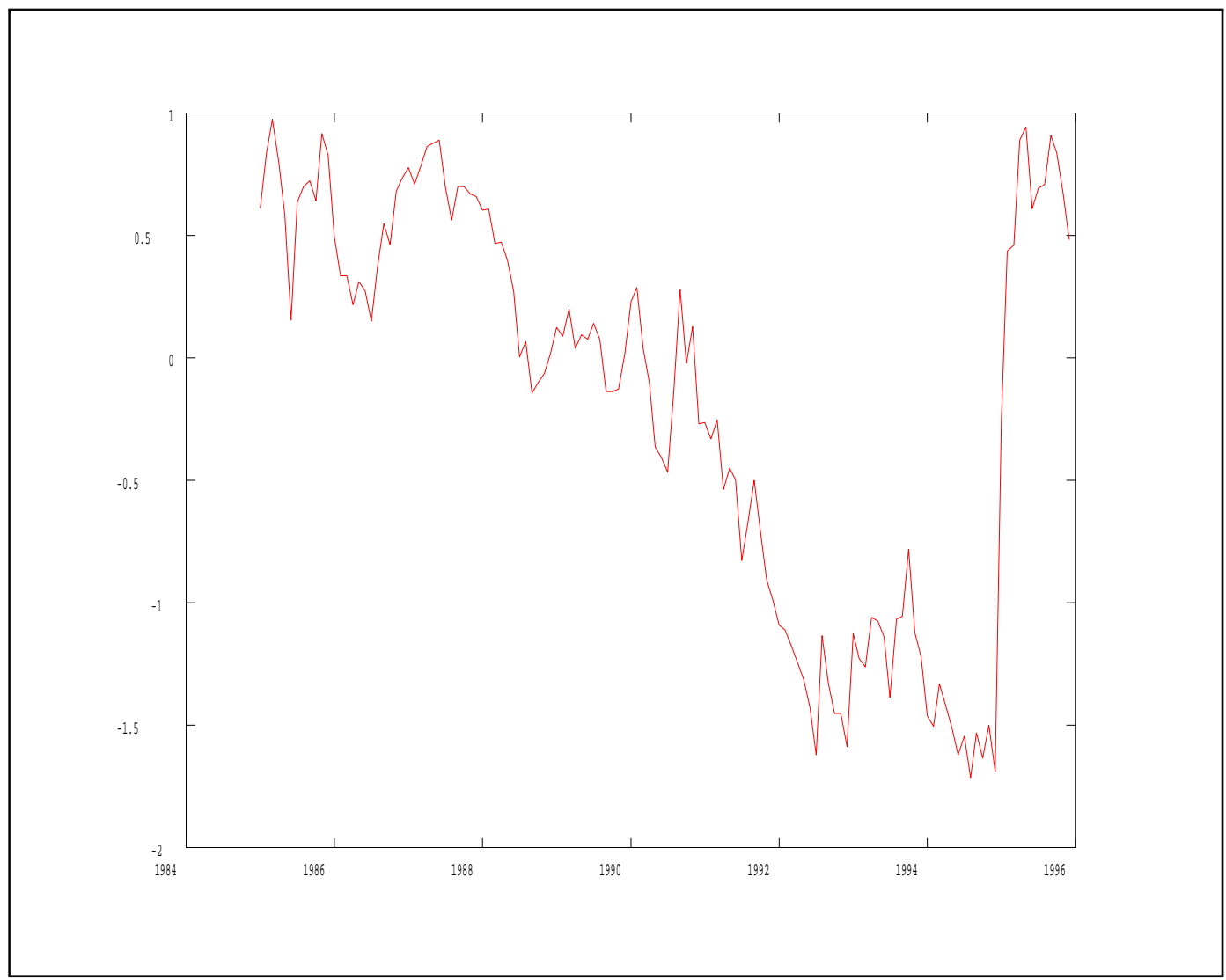

Figure 2: Monthly Trade Balance f.o.b. in Billions of U.S. Dollars.

Source: Banco de Mexico, Indicadores Economico, various issues. 